\title{
NEW GENERALIZATIONS OF BAZILEVIČ MAPS
}

\author{
K. O. BABALOLA
}

Abstract. In this work we study, via Caratheodory maps with normalization by other than unity, a generalization of certain well-known subfamily of Bazilevič functions using the also well-known Salagean derivative operator.

Mathematics subject classification (2010): 30C45.

Keywords and phrases: Bazilevič maps, caratheodory maps with normalization by other than unity, analytic and univalent functions.

\section{REFERENCES}

[1] S. Abdulhalim, On a class of analytic functions involving the Salagean differential operator, Tamkang J. Math., 23 (1) (1992), 51-58.

[2] K. O. BABAlOLA, Some new results on a certain family of analytic functions defined by the Salagean derivative, Unpublished Doctoral Thesis, University of Ilorin, Nigeria, 2005.

[3] K. O. Babalola AND T. O. OpOOLA, Radius problem for a certain family of analytic and univalent functions, Advances in Inequalities for Series, Nova Science Publishers (2008), 19-24.

[4] K. O. Babalola, On n-starlike integral operators, Kragujevac Journal of Mathematics, 34 (2010), $61-71$.

[5] K. O. Babalola, New insights into Bazilevič maps, Analele Universitatii Oradea, Fasc. Matematica. Tom XXIII, Issue I (2016), 5-10.

[6] I. E. BAZILEVIČ, On a case of integrability by quadratures of the equation of Loewner-Kufarev, Mat. Sb., 37 (79) (1955), 471-476 (in Russian).

[7] P. N. Chichra, Regular functions $f(z)$ for which $z f^{\prime}(z)$ is $\alpha$-spiral-like, Proc. Amer. Math. Soc., 49 (1) (1975), 151-160 (in Russian).

[8] S. S. Miller And P. T. Mocanu, Second order differential inequalities in the complex plane, J. Math. Anal. Appl., 65 (1978), 289-305.

[9] G. S. Salagean, Subclasses of univalent functions, Lecture Notes in Math. 1013 (1983), 362-372, Springer-Verlag, Berlin, Heidelberg and New York.

[10] R. Singh, On Bazilevič functions, Proc. Amer. Math. Soc., 38 (2) (1973), 261-271.

[11] L. ŠPAČEK, Přespěvek k teorii funkci prostyčh, Časopis Pěst. Mat. Fys. 62 (1933), 12-19. 